\title{
Przegląd metod pomiaru emisji metanu wraz z analizą możliwości ich zastosowania do pomiaru emisji metanu z gazociągów
}

\begin{abstract}
W artykule dokonano przeglądu metod pomiaru emisji metanu stosowanych w gazownictwie. Przedstawiono charakterystykę różnych metod pomiaru jego emisji: korelacyjnej, z zastosowaniem środka spieniającego, z użyciem worków gazoszczelnych, znacznikowych, bilansowych, pomiaru z opływem powietrza, opartych na analizie obrazów rejestrowanych w podczerwieni. Przeanalizowano możliwość zastosowania poszczególnych metod pomiaru emisji metanu do pomiarów emisji z elementów podziemnych (gazociągów). Przeprowadzone analizy wykazały, że do pomiarów emisji metanu z gazociągów najlepiej nadaje się metoda $\mathrm{z}$ opływem powietrza.
\end{abstract}

Słowa kluczowe: sieci gazowe, emisja metanu, pomiar emisji metanu.

\section{A review of methane emission measurement methods along with an analysis of their applicability to the measurement of methane emissions from gas pipelines}

This article reviews methane emission measurement methods used in the gas industry. The characteristics of the methane emission measurement methods: correlation methods, soapy water methods, bagging methods, indicator methods, direct flow measurement method and pressure decay method, air flow methods and infrared imaging techniques. The possibility of applying individual methods of measurement of methane emissions for measurements of underground elements (gas pipelines) has been analyzed. The analyzes carried out showed that for methane emission from gas pipelines the air flow method is best suited.

Key words: gas networks, methane emission, measuring methane emission.

\section{Wstęp}

Inwentaryzacja emisji metanu z systemu gazowniczego, jako element walki ze zmianami klimatycznymi, stała się interesującym zagadnieniem już na początku lat 90 . XX wieku. Na przestrzeni lat zmianom uległy stosowane metody pomiaru emisji lotnych metanu wykorzystywane do wyznaczania współczynników emisji. Analiza dostępnych metod pokazuje jednak, że większość z nich koncentruje się na elementach systemów gazowych zlokalizowanych powyżej powierzchni gruntu, a ich adaptacja do pomiaru wielkości emisji metanu z gazociągów nie zawsze jest możliwa do wykonania lub wymaga odkrycia nieszczelnego fragmentu gazociągu, co znacząco wydłuża czas prowadzenia badań oraz podnosi ich koszty. Dlatego też w wielu przypadkach do wy- znaczenia wielkości emisji metanu z gazociągów stosowane są literaturowe współczynniki emisji. Jednak ze względu na ich duże zróżnicowanie oraz niewielką ilość obiektywnych przesłanek mówiących o tym, który ze współczynników emisji w najlepszy sposób charakteryzuje dany system gazowniczy, mogą przyczyniać się one do uzyskania nieprawidłowych wyników inwentaryzacji emisji metanu $[9,20]$. Z tego względu interesującym zagadnieniem wydaje się być wskazanie, które z dostępnych metod pomiaru wielkości emisji metanu mogą być stosowane podczas pomiarów prowadzonych w gazociągach oraz jakie powinny być spełnione wymagania techniczne, aby pomiar daną metodą stał się możliwy do wykonania i był wiarygodny. 


\section{Podział metod stosowanych w pomiarach emisji metanu}

Metody pomiaru wielkości emisji metanu z elementów systemu gazowego można podzielić na:

- korelacyjne, w których do wyznaczenia wielkości emisji metanu wykorzystuje się wyniki pomiarów jego zawartości w powietrzu oraz odpowiednie równania korelacyjne,

- z zastosowaniem środka spieniającego, które wykorzystują zależność pomiędzy wielkością tworzących się pęcherzyków w cieczy zawierającej środek powierzchniowo czynny a ilością gazu wydobywającego się z nieszczelnego elementu,

- z zastosowaniem worków gazoszczelnych - w których gaz $\mathrm{z}$ nieszczelnego elementu gromadzony jest w odpowiednich workach gazoszczelnych,
- $\quad$ znacznikowe - wykorzystujące gazowe substancje znacznikowe wprowadzane do nieszczelnego układu,

- bilansowe,

- $\quad$ pomiaru z opływem powietrza - jest to jedna z najpopularniejszych kategorii metod stosowanych do pomiarów wielkości emisji metanu,

- oparte na analizie obrazów rejestrowanych w podczerwieni. Mimo że obecnie dostępnych jest wiele metod pomiaru wielkości emisji metanu z sieci lub instalacji gazowych, zagadnienia te nie są łatwe. Dodatkowo nie każda z wymienionych metod może znaleźć zastosowanie do pomiarów emisji metanu z elementów podziemnych.

\section{Metody korelacyjne}

Spośród wielu metod pomiaru emisji metanu jedynie metoda korelacyjna doczekała się normalizacji. Została ona opisana w normie PN-EN 15446:2008 Niekontrolowana i rozproszona emisja $w$ sektorze przemysłowym - Pomiar emisji par wydobywających się z nieszczelnych instalacji i przewodów. Przedstawiona w normie metoda pozwala na przeliczenie zmierzonej zawartości metanu w powietrzu na odpowiednie wartości emisji metanu. Przeliczenia te wykonywane są przy użyciu odpowiednich równań korelacyjnych [21]. Jednak słuszność takiego podejścia budzi poważne zastrzeżenia branży gazowniczej $[4,5]$. Ponadto opisana w normie procedura pomiaru zawartości metanu w powietrzu zakłada, że wylot sondy urządzenia umieszcza się na powierzchni nieszczelnego elementu. Następnie, przesuwając sondę wokół nieszczelnego elementu, należy zidentyfikować miejsce o najwyższym stężeniu meta- nu w powietrzu i dokonać w nim końcowego pomiaru zawartości metanu w powietrzu. Zgodnie z normą [21] wynik tego pomiaru przeliczony z użyciem równania korelacyjnego odpowiada emisji metanu $z$ danego elementu. Taki sposób prowadzenia pomiarów wyklucza możliwość zastosowania ich do badania wielkości emisji metanu z elementów podziemnych, bez wcześniejszego odkrycia miejsca występowania nieszczelności. W przypadku gazociągów oznacza to, że metodę tę można stosować jedynie w połączeniu z metodą lokalizacji nieszczelności [8]. Norma [21] nie odnosi się w żaden sposób do możliwości wykorzystania wyników pomiaru stężenia metanu w powietrzu glebowym, dlatego też należy założyć, że wynik taki jest nieużyteczny do wyznaczenia wielkości emisji metanu co najmniej w zakresie równań korelacyjnych opisanych w normie.

\section{Metody z zastosowaniem środka spieniającego}

Metoda pomiaru emisji metanu z zastosowaniem wodnego roztworu środka spieniającego (powierzchniowo czynnego) jest najprostszą technicznie i najtańszą metodą pomiaru wielkości emisji metanu. Polega ona na powlekaniu miejsc uchodzenia gazu wodnym roztworem środka powierzchniowo czynnego i obserwacji wielkości wydobywających się z miejsca uchodzenia pęcherzyków. Metoda ta pozwala na pomiar wielkości emisji metanu w zakresie od 0,1 do 100 l/h [17]. Poniżej tego zakresu powstawanie pęcherzyków może być niezauważalne, natomiast powyżej może dochodzić do zrywania przez gaz powłoki ze środka powierzchniowo czynnego nałożonej na miejsce, w którym powstaje nieszczelność. Istotną wadą tej metody jest duża niepewność pomiaru sięgająca nawet 500\%, która związana jest głównie z subiektywnością oceny wielkości powstających pęcherzyków w spienionym roztworze środka powierzchniowo czynnego [17]. Dlatego też powinna ona być traktowana wyłącznie jako metoda wskaźnikowa, półilościowa. Dodatkowo zastosowanie tej metody na nieszczelnym gazociągu wymagałoby jego odkrycia w miejscu stwierdzenia nieszczelności oraz dokładnego oczyszczenia miejsca wycieku przed rozpoczęciem pomiaru.

\section{Metody z zastosowaniem worków gazoszczelnych}

Metoda pomiaru wielkości emisji metanu z zastosowaniem worków gazoszczelnych została opracowana przez EPA
(Environmental Protection Agency) w 1995 r. Pomiar wielkości emisji metanu w tej metodzie polega na szczelnym 
owinięciu miejsca wycieku gazoszczelną powłoką i skierowaniu wypływającego przez nieszczelność gazu do przepływomierza, który mierzy wielkość wypływu gazu [1]. Dużym ograniczeniem tej metody jest konieczność uzyskania takiego ciśnienia oraz przepływu gazu, które zagwarantują uzyskanie prawidłowego wyniku. Dlatego też posiada ona również drugi wariant, w którym do urządzenia mierzącego przepływ gazu doprowadza się, oprócz gazu uchodzącego przez nieszczelność, dodatkowy gaz, np. powietrze atmosferyczne. Dodatkowy gaz doprowadzany jest za pomocą pompy lub bezpośrednio z butli. Zastosowanie tego wariantu wymaga jednak przeprowadzenia oprócz pomiaru przepływu gazu również pomiaru stężenia metanu na wylocie z przepływomierza [17]. Istnieje również inna odmiana tej metody, w której miejsce wycieku zostaje owinięte nieprzepuszczalnym materiałem. W powstałej w ten sposób przestrzeni gromadzony jest metan oraz gaz inertny, np. azot, którego dopływ odbywa się w kontrolowanych warunkach z po- miarem prędkości przepływu. W takim przypadku szybkość wycieku metanu z nieszczelnego elementu można obliczyć zgodnie z równaniem (1) [14]:

$$
E_{\mathrm{CH}_{4}}=F_{\text {azot }} \cdot C_{\mathrm{CH}_{4}}
$$

gdzie:

$E_{\mathrm{CH}_{4}}-$ emisja metanu $\left[\mathrm{m}^{3} / \mathrm{h}\right]$,

$F_{\text {azot }}$ - prędkość przepływu gazu inertnego $\left[\mathrm{m}^{3} / \mathrm{h}\right]$,

$C_{\mathrm{CH}_{4}}$ - zmierzone stężenie metanu [\%].

Metoda ta niezależnie od zastosowanego rozwiązania technicznego, podobnie jak wcześniej opisane metody, ma ograniczone możliwości zastosowania w przypadku infrastruktury podziemnej. Użycie tej metody w stosunku do nieszczelnego gazociągu wymaga nie tylko dokładnego zlokalizowania nieszczelności, ale także odkrycia miejsca występowania nieszczelności i takiego oczyszczenia gazociągu w tym miejscu, które pozwoli na szczelne założenie osłony.

\section{Metody znacznikowe}

Metody znacznikowe mogą być wykorzystywane nie tylko do lokalizowania miejsc występowania nieszczelności [8], ale także do pomiaru wielkości emisji metanu. W metodach tych najczęściej stosowanymi znacznikami są heksafluorek siarki $[3,7]$ lub alifatyczne węglowodory nienasycone $[12,15]$. Metoda znacznikowa polega na wprowadzaniu znacznika w formie gazowej do sieci w pobliżu zlokalizowanej nieszczelności. Znacznik wprowadzany jest do sieci ze stałą znaną prędkością, a następnie prowadzony jest pomiar zawartości metanu oraz substancji znacznikowej w powietrzu [10] i według równania (2) wyliczana jest wielkość emisji metanu [15]:

$$
E_{\mathrm{CH}_{4}}=Q_{\text {znacznika }} \times \frac{C_{\mathrm{CH}_{4}}-C_{\mathrm{CH}_{4}, \text { to }}}{C_{\text {znacznika }}-C_{\text {znacznika,tło }}}
$$

gdzie:

$E_{\mathrm{CH}_{4}}-$ emisja metanu $[\mathrm{g} / \mathrm{s}]$,

$Q_{\text {znacznika }}$ - szybkość uwalniania znacznika do sieci gazowej [g/s],

$C_{\mathrm{CH}_{4}}$ - zmierzone stężenie metanu $\left[\mathrm{g} / \mathrm{m}^{3}\right]$,

$C_{\mathrm{CH}_{4} \text {, to }}$ - stężenie metanu zmierzone jako tło $\left[\mathrm{g} / \mathrm{m}^{3}\right]$,

$C_{\text {znacznika }}$ - zmierzone stężenie znacznika $\left[\mathrm{g} / \mathrm{m}^{3}\right]$,

$C_{\text {znacznika,to }}$ - stężenie znacznika zmierzone jako tło $\left[\mathrm{g} / \mathrm{m}^{3}\right]$.

Metoda znacznikowa zakłada, że w miejscu wycieku gazu substancja znacznikowa uległa całkowitemu zmieszaniu z gazem ziemnym oraz że cząsteczki metanu i znacznika charakteryzują się takim samym stopniem dyfuzji, tzn. że stosunek stężenia metanu do stężenia znacznika jest taki sam w sieci oraz poza nią [10]. Znacznik do sieci gazowej wprowadza się głównie na stacjach gazowych. Istnieją jednak istotne ograni- czenia związane z możliwością wprowadzenia znacznika do gazociągu. Polegają one głównie na braku odpowiedniej infrastruktury umożliwiającej taki zabieg. Jeżeli nieszczelność zlokalizowana jest w znacznej odległości od miejsca, w którym można wprowadzić znacznik do gazociągu (np. stacji redukcyjno-pomiarowej), wtedy należy użyć większej ilości znacznika, co w istotny sposób wpływa na koszt realizacji takiego pomiaru. Kolejnym istotnym ograniczeniem w stosowaniu tej metody jest fakt, że może być ona wykorzystywana tylko na nierozgałęzionym odcinku gazociągu oraz pomiędzy miejscem wprowadzenia znacznika a lokalizacją mierzonej nieszczelności nie mogą występować inne nieszczelności. Dodatkowo zastrzeżenia może budzić fakt wprowadzania do gazociągu znacznika, szczególnie w postaci heksafluorku siarki, gdyż część substancji znacznikowej wraz z gazem dotrze do odbiorców końcowych tego paliwa, gdzie najprawdopodobniej ulegnie spaleniu. Pod wpływem wysokiej temperatury następuje termiczny rozkład heksafluorku siarki i mogą tworzyć się związki takie jak fluorowodór oraz tlenek siarki(IV), które w kontakcie z wodą mogą przyśpieszać korozję. Dodatkowo fluorowodór jest gazem toksycznym i żrącym. Takich wątpliwości nie budzi wprowadzanie do sieci gazowej węglowodorów nienasyconych, jednak ich oznaczenie wspólnie z metanem z wystarczająco niską granicą oznaczalności wymaga zastosowania odpowiedniej aparatury. Najczęściej do tego typu pomiarów stosowane są spektroskopy $\mathrm{z}$ transformatą Fouriera (FTIR) lub spektroskopy CRDS, pozwalające na pomiar śladowych zawartości węglowodorów w powietrzu $[12,15]$. 


\section{Metody bilansowe}

W kategorii metod bilansowych wyróżnić można trzy z nich:

- pomiar bezpośredni, który wymaga utrzymania stałego ciśnienia gazu w odizolowanym od reszty sieci fragmencie nieszczelnego gazociągu,

- pomiar spadku ciśnienia w odizolowanym fragmencie gazociągu,

- zmiana ciśnienia wykorzystująca zasadę, według której natężenie wypływu gazu w miejscu wycieku jest proporcjonalne do ciśnienia gazu panującego w sieci.

W każdej z tych metod niezbędne jest zapewnienie, że $\mathrm{w}$ trakcie trwania pomiarów gaz $\mathrm{z}$ danego odcinka nie będzie pobierany przez klientów lub że pobór ten będzie stały [1, 17].

Najtrudniejsza do zrealizowania w warunkach rzeczywistych jest metoda oparta na pomiarze spadku ciśnienia, gdyż wymaga całkowitego odizolowania badanego odcinka gazociągu. Wyizolowany fragment gazociągu napełniany jest gazem do określonego ciśnienia, po czym następuje pomiar spadku ciśnienia gazu w gazociągu w określonych odstępach czasu. Szybkość spadku ciśnienia jest funkcją szybkości wypływu gazu przez nieszczelności zlokalizowane na danym odcinku [17]. Medium gazowym, przy użyciu którego realizowane są pomiary, może być zarówno gaz ziemny, jak i gaz inertny. Metoda pomiaru bezpośredniego jest również mało odporna na ewentualne zmiany wielkości zużycia gazu przez klientów indywidualnych, dlatego też powinna być realizowana przy całkowitym odizolowaniu badanego fragmentu gazociągu. W takiej sytuacji do wyizolowanego fragmentu gazociągu wprowadzany jest gaz w celu uzyskania ciśnienia zbliżonego do ciśnienia roboczego panującego na danym fragmencie gazociągu. Następnie dokonuje się pomiaru ilości gazu za-

tłaczanego do gazociągu, niezbędnego do utrzymania w nim stałego ciśnienia. Pomiar z wykorzystaniem tej metody może być prowadzony również przy utrzymaniu jednostajnego poboru gazu z sieci. W takim przypadku wymagany jest nie tylko pomiar ilości gazu zatłoczonego do sieci w celu utrzymania stałego ciśnienia, ale także pomiar ilości gazu dostarczonego odbiorcom. W warunkach rzeczywistych realizacja tej metody w wariancie $\mathrm{z}$ zachowaniem poboru gazu przez odbiorców jest możliwa do wykonania wyłącznie w przypadku takich odcinków gazociągów, do których przyłączeni są pojedynczy odbiorcy przemysłowi zużywający stałe ilości gazu. Natomiast metoda bilansowa oparta na zależności liniowej natężenia wypływu gazu od ciśnienia panującego w gazociągu wydaje się mieć najszersze możliwości zastosowania. Realizacja pomiarów wielkości emisji metanu tą metodą opiera się na trzech podstawowych krokach [1]:

- krok 1 - pomiar natężenia przepływu gazu w gazociągu w różnych warunkach ciśnienia; pomiaru tego dokonuje się na wejściu badanego odcinka gazociągu. Na podstawie otrzymanych wyników wykreśla się zależność natężenia przepływu gazu od ciśnienia;

- krok 2 - oszacowanie zużycia gazu przez odbiorców, wartość tę szacuje się przez liniową ekstrapolację wartości zmierzonych w kroku 1 do przecięcia z osią Y;

- krok 3 - oszacowanie wielkości emisji gazu z nieszczelnego odcinka gazociągu, wartość ta stanowi różnicę pomiędzy wyznaczoną interpolacyjnie wartością natężenia przepływu gazu $\left(G F_{\text {całkowite }}\right)$ a oszacowanym zużyciem gazu przez odbiorców ( $\left.G F_{\text {odbiorcy }}\right)$.

Zasadę metody opartej na wykorzystaniu zależności natężenia wypływu gazu od ciśnienia przedstawiono na rysunku 1.

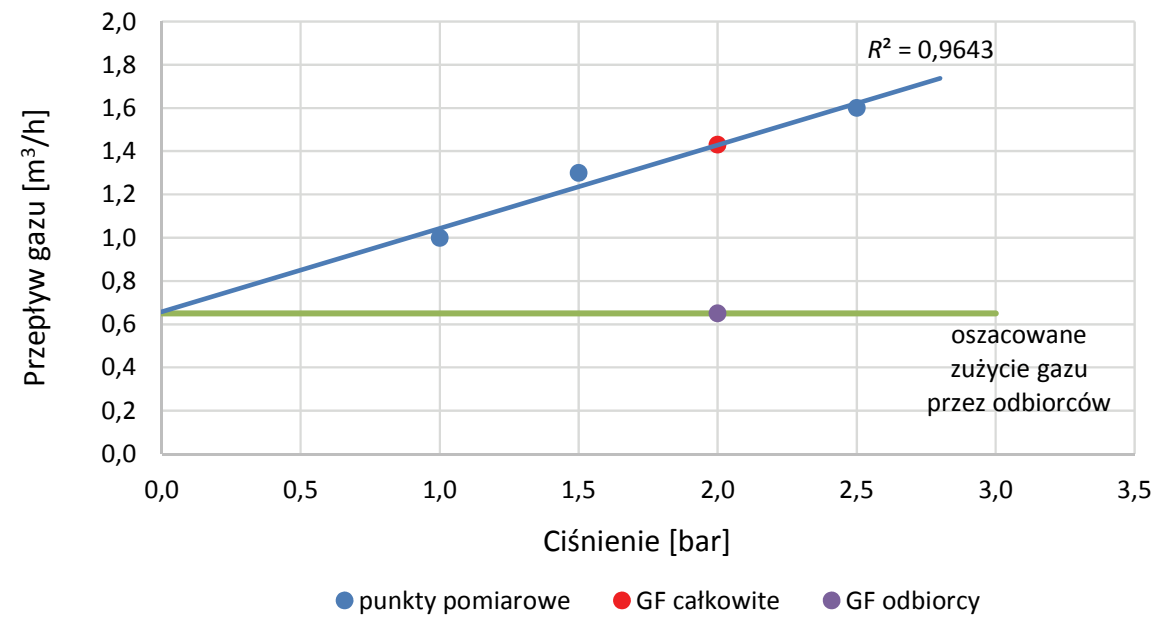

Rys. 1. Schemat wyznaczania wyniku w metodzie bilansowej opartej na zależności natężenia wypływu gazu od ciśnienia [1]

Ostatnia z opisanych metod bilansowych stawia najmniej restrykcyjne wymagania względem konieczności wyizolowania danego odcinka gazociągu. Pomiar tą metodą może odbywać się na odcinku gazociągu niewyłączonym z eksploatacji, co stanowi istotną zaletę. Należy pamiętać o tym, że niepewność wyznaczenia wielkości emisji metanu w dużej mierze zależeć będzie od utrzymania stałego poboru gazu przez odbiorców [1]. Niestety parametr ten jest trudny do kontroli w warunkach rzeczywistych, a duże dobowe zmiany w ilości gazu zużywanego przez odbiorców mogą dyskwalifikować tę metodę do szacowania wielkości emisji metanu.

Analizując informacje dotyczące metod bilansowych, można stwierdzić, że są to metody, które służą do szacowania wielkości 
emisji metanu z nieszczelnych gazociągów. Nie można jednak ich nazwać metodami pomiarowymi, szczególnie w przypadku, gdy nie dochodzi do całkowitego odizolowania badanego gazociągu. Jednak mają one również istotną zaletę, tj. nie wy- magają lokalizacji miejsca występowania nieszczelności. Dodatkowo metody bilansowe pozwalają na oszacowanie całkowitej wielkości emisji metanu z danego odcinka gazociągu, nawet w przypadku, gdy zawiera on więcej niż jedną nieszczelność.

\section{Metody pomiaru z opływem powietrza}

Do pomiarów wielkości emisji metanu najczęściej wykorzystywane są metody z opływem powietrza, co spowodowało, że doczekały się one dostępnych w sprzedaży gotowych zestawów pomiarowych. Taki zestaw stanowi między innymi urządzenie Hi Flow Sampler (HFS) wraz z oprzyrządowaniem. Niezależnie od zastosowanych rozwiązań technicznych metoda ta polega na tym, że wymuszony przepływ powietrza w miejscu występowania nieszczelności kieruje uchodzący gaz do układu pomiarowego, w którym następuje pomiar prędkości przepływu gazu oraz pomiar stężenia metanu w przepływającym gazie. Dodatkowo jest prowadzony pomiar stężenia metanu w powietrzu atmosferycznym stanowiącym tło dla niniejszych pomiarów. W metodzie tej wielkość emisji metanu oblicza się na podstawie równania (3) [1, 14]:

$$
E_{\mathrm{CH}_{4}}=F_{\text {powietrza }} \cdot\left(C_{\mathrm{CH}_{4}}-C_{\mathrm{CH}_{4}, \text { to }}\right)
$$

gdzie:

$E_{\mathrm{CH}_{4}}$ - emisja metanu [1/min],

$F_{\text {powietrza }}-$ prędkość przepływu powietrza [1/min],

$\mathrm{C}_{\mathrm{CH}_{4}}$-zmierzone stężenie metanu w mieszaninie powietrzegaz ziemny [\%],

$C_{\mathrm{CH}_{4}, \text { to }}-$ stężenie metanu zmierzone jako tło [\%].

W pomiarach wielkości emisji metanu metodą z opływem powietrza największą trudność sprawia taki dobór oprzyrządowania oraz prędkości przepływu powietrza, aby cały metan uchodzący z nieszczelnego elementu został skierowany do układu pomiarowego. Dodatkowo w przypadku niewielkich nieszczelności istotne jest, by prędkość przepływu powietrza nie była zbyt duża, gdyż powodować to będzie znaczne obniżenie stężenia metanu w powstającej mieszaninie i utrudniać przeprowadzenie pomiarów z odpowiednią dokładnością. Metoda ta może być z sukcesem stosowana do pomiarów wielkości emisji na etapie wydobycia, przesyłu oraz dystrybucji gazu. Używana jest najczęściej do pomiarów wielkości emisji z elementów takich jak głowice odwiertów, separatory, osuszacze, filtry, sprężarki, segmenty orurowania, stacje redukcyjno-pomiarowe oraz do pomiaru wielkości emisji z różnego typu połączeń występujących pomiędzy elementami armatury gazowej. Porównanie metody pomiaru wielkości emisji z opływem powietrza z metodą z wykorzystaniem worków gazoszczelnych wykazało, że metoda z opływem powietrza jest znacznie szybsza oraz pozwala na lepszą kontrolę stopnia rozcieńczenia uchodzącego gazu gazem inertnym, dzięki czemu charakteryzuje się ona niższą granicą oznaczalności [11]. Zastosowanie metody pomiaru wielkości emisji metanu z opływem powietrza było analizowane również w kontekście możliwego wykorzystania tej metody do pomiarów emisji metanu z gazociągów [6]. W przeprowadzonych przez Gas Technology Institute (GTI) badaniach polowych stosowano tę metodę zarówno do pomiarów na odsłoniętej nieszczelności, jak i do pomiarów prowadzonych z powierzchni gruntu metodą komór dyfuzyjnych. W obu analizowanych przypadkach uzyskano akceptowalną zgodność wyników. Procedura pomiaru wielkości emisji metanu z zastosowaniem komór dyfuzyjnych opisana przez GTI zakładała w pierwszej kolejności wyznaczenie miejsca występowania nieszczelności oraz obszaru, w którym następuje emisja metanu z powierzchni ziemi. Następnie dokonywano pomiaru emisji metanu na wyznaczonym obszarze z zastosowaniem komór dyfuzyjnych o wymiarach 1,22 na 2,44 m. W pomiarach wykorzystano urządzenie HFS; wyniki pomiarów uzyskane przez GTI przedstawiono na rysunku 2.

Zastosowana przez GTI procedura wykazuje wyraźną liniową korelację pomiędzy wynikami uzyskanymi przy użyciu HFS a odczytami z gazomierza. Zauważyć można jednak, że

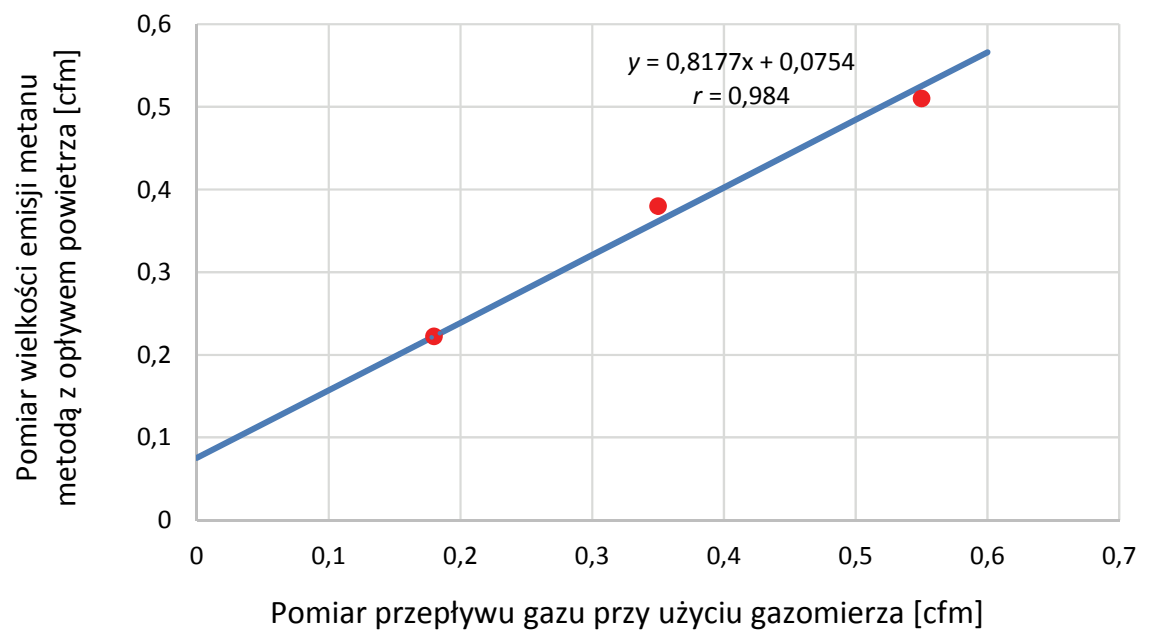

Rys. 2. Wyniki pomiarów wielkości emisji metanu metodą z opływem powietrza wykonane przez GTI [6] 
wyniki pomiaru wielkości emisji metanu przy użyciu metody z opływem powietrza są zaniżone w stosunku do wartości rzeczywistych o około 20\%. Przedstawione przez GTI badania dowodzą, że metoda pomiaru emisji metanu z opływem powietrza może być stosowana do pomiarów emisji z gazociągów bez konieczności odkrycia gazociągu, w zakresie emisji od 2,8 do 17,0 1/min. Metoda pomiaru emisji metanu z opływem powietrza jest jedyną metodą, $\mathrm{z}$ analizowanych dotychczas, która stwarza warunki do prowadzenia pomiarów emisji metanu z nieszczelnego fragmentu gazociągu, bez konieczności jego odkrycia lub wyłączenia nieszczelnego gazociągu w trakcie prowadzenia badań.

\section{Metody pomiaru oparte na analizie obrazów uzyskanych w podczerwieni}

Promieniowanie podczerwone oraz metody termowizyjne wykorzystywane są z powodzeniem do identyfikacji miejsc uchodzenia gazu $[2,13,16,18]$, jednak ich zastosowanie do pomiarów wielkości emisji metanu nie wydaje się już takie oczywiste. Mimo to prowadzone są prace nad wykorzystaniem tego typu metod do pomiarów wielkości emisji metanu [19]. Metoda taka została opracowana na podstawie analizy obrazów termowizyjnych otrzymanych z różnych nieszczelnych elementów z wykorzystaniem symulacji Monte Carlo oraz metod statystycznych. Ilościowe określenie wielkości wycieku jest więc oparte wyłącznie na podejściu statystycznym na podstawie wielkości obłoku obserwowanego w podczerwieni [19]. W metodzie tej na wielkość obłoku ma wpływ nie tylko ciśnienie oraz ilość uwalnianego gazu, ale także warunki klimatyczne. Metoda oparta na analizie obrazów uzyskanych w podczerwieni została przetestowana do oceny wielkości wycieków gazu ziemnego w realnych warunkach pogodowych, a uzyskane wyniki potwierdziły możliwość jej stosowania do pomiaru wycieków mniejszych niż $0,1 \mathrm{~kg} / \mathrm{s}$, przy czym prędkość wiatru jest głównym czynnikiem wpływającym na dokładność pomiarów [19]. Metody pomiaru emisji metanu z wykorzystaniem analizy obrazów otrzymanych w podczerwieni nie są metodami popularnymi, jednak nie jest wykluczone, że stanowią one dobrą alternatywę dla prowadzenia pomiarów emisji metanu z gazociągów z zachowaniem typowej pracy gazociągu i bez konieczności odkrycia jego nieszczelnego fragmentu.

Przeprowadzone analizy pokazały, że istnieje wiele dostępnych metod pomiaru wielkości emisji metanu z nieszczelnych elementów infrastruktury gazowej. Jednak większość $\mathrm{z}$ nich jest przeznaczona do pomiaru emisji metanu $\mathrm{z}$ elementów nadziemnych, dlatego też ich zastosowanie w przypadku gazociągów wymaga odkrycia miejsca występowania nieszczelności lub wyizolowania nieszczelnego fragmentu gazociągu. Jedynie metody oparte na analizie obrazów uzyskanych w podczerwieni oraz metody z opływem powietrza mogą zostać wykorzystane do pomiarów wielkości emisji metanu z nieszczelnych gazociągów podczas typowej pracy gazociągu i bez konieczności odkrycia nieszczelnego fragmentu gazociągu.

\section{Podsumowanie}

Przeprowadzona analiza dostępnych metod pomiaru wielkości emisji metanu wykazała, że do tego typu pomiarów z gazociągów mogą być stosowane metody korelacyjne, metody z zastosowaniem środka spieniającego oraz metody z zastosowaniem worków gazoszczelnych. Jednak ich wykorzystanie do pomiarów wielkości emisji metanu z gazociągów nie jest zalecane, gdyż są metodami inwazyjnymi i wymagają odkrycia nieszczelnego fragmentu gazociągu. Za nieinwazyjną uznać można metodę znacznikową, jednak jej zastosowanie w przypadku gazociąów może być utrudnione ze względu na problemy przy wprowadzaniu znacznika do gazociągu. Metoda ta budzi również zastrzeżenia w kontekście wykorzystania substancji będących znacznikami. Przeznaczone do pomia- rów wielkości emisji metanu z gazociągów bilansowe metody pomiaru emisji nie są w pełni bezinwazyjne, gdyż wymagają w optymalnych warunkach odizolowania badanego odcinka gazociągu lub w wersji uproszczonej utrzymania stałego poboru gazu przez odbiorców, co w znacznym stopniu utrudnia realizację pomiarów. Jedynie metody pomiaru emisji metanu prowadzone $\mathrm{z}$ opływem powietrza lub metody oparte na analizie obrazów uzyskanych w podczerwieni pozwalają na prowadzenie pomiaru wielkości emisji metanu z nieszczelnego gazociągu w sposób bezinwazyjny. Jednak metody oparte na analizie obrazów uzyskanych w podczerwieni do tej pory nie doczekały się wielu komercyjnych rozwiązań, stąd też ich praktyczne wykorzystanie jest obecnie mocno ograniczone.

Prosimy cytować jako: Nafta-Gaz 2018, nr 1, s. 37-43, DOI: 10.18668/NG.2018.01.04

Artykuł nadesłano do Redakcji 16.10.2017 r. Zatwierdzono do druku 29.11.2017 r.

Artykuł powstał na podstawie pracy statutowej pt.: Analiza możliwości oceny wielkości emisji metanu z sieci gazu ziemnego - praca INiG - PIB na zlecenie MNiSW; nr zlecenia: 0062/GE/16, nr archiwalny: DK-4100-62/16. 


\section{Literatura}

[1] Barroso J., Solis J.M., Ballester J., Pina A.: Evaluation of methane emissions from polyethylene gas distribution system at medium pressure. Journal of Natural Gas Science and Engineering 2009, vol. 1, s 144-153.

[2] Basiura M., Rataj M.: Wykrywanie nieszczelności w instalacjach i urzadzeniach gazowych za pomoca metody obserwacji w paśmie podczerwieni. Gaz, Woda i Technika Sanitarna 2013, nr 11, s. 426-429.

[3] Deighton M.H., Williams S.R.O., Hannah M.C., Eckard R.J., Boland T.M., Wales W.J., Moate P.J.: A modified Sulphur heksafluoride tracer technique enables accurate determination of enteric methane emissions from ruminants. Animal Feed Science and Technology 2014, vol. 197, s. 47-63.

[4] Demusiak G.: Wybrane metody szacowania emisji metanu na tłoczniach gazu. Gaz, Woda i Technika Sanitarna, 2014, nr 11, s. 414-416.

[5] Dyakowska E., Pęgielska M.: Porównanie dokładności dwóch metod pomiaru emisji lotnych - wg normy EN 15466 oraz $z$ zastosowaniem urzadzenia Hi Flow Sampler - wyniki projektu GERG. Materiały konferencyjne, Konferencja NaukowoTechniczna Forgaz 2016, s. 45-56.

[6] Farrag K.: Improving Methane Emission Estimate for Natural Gas Distribution Companies - Phase II - PE pipelines. Gas Technology Institute, Des Plaines, Illinois 2013, s. 17-36.

[7] Foster Witting T.A., Thoma E.D., Green B., Hater G.R., Swan N.D., Chanton J.P.: Development of a mobile tracer correlation method for assessment of air emissions from landfills and other area sources. Atmospheric Environment 2015, vol. 102, s. 323-330.

[8] Holewa-Rataj J., Kukulska-Zając E.: Przeglad metod wykrywania nieszczelności sieci gazowych. Nafta-Gaz 2017, nr 11, s. 3-9, DOI: 10.18668/NG.2017.11.07.

[9] Holewa-Rataj J., Kukulska-Zając E.: Przegląd współczynników emisji metanu dla gazociagów. Gaz, Woda i Technika Sanitarna 2017, nr 7, s. 282-288.

[10] Kirchgessner D.A., Lott R.A., Cowgill R.M., Harrison M.R., Shires T.M.: Estimate of methane emissions from the U.S. natural gas industry. Chemosphere 1997, vol. 35, s. 1365-1390.

[11] Kuo J., Hicks T.C., Draken B., Chan T.F.: Estimation of methane emission from California natural gas industry. Journal of the Air \& Waste Management Association 2015, vol. 65, s. 844-855.
[12] Kwok C.E.Y., Muller D., Caldow C., Lebegue B., Monster J.G., Rella C.W., Scheutz C., Schmidt M., Ramonet M., Warneke T., Broquet G., Ciais P.: Methane emission estimate using chamber and tracer release experiments for a municipal waste water treatment plant. Atmospheric Measurement Techniques 2015, vol. 8, s. 2853-2867.

[13] Mandal P.C.: Gas Leak Detection in Pipelines \& Repairing System of Titas Gas. Journal of Applied Engineering (JOAE) 2014, vol. 2, nr 2, s. 23-34.

[14] Mandal P.C., Chowdhury S., Morshed S.M.: Fugitive methane emissions from the natural gas distribution network of Titas Gas and the environmental risks. WIT Transactions on Ecology and the Environment 2015, vol. 206, s. 137-148.

[15] Monster J.G., Samuelsson J., Kjeldsen P., Rella C.W., Scheutz C.: Quantifying methane emissions from fugitive sources by combining tracer release and downwing measurements A sensitivity analysis based on multiple field surveys. Waste Management 2014, vol. 34, s. 1416-1428.

[16] Murvaya P.S., Sileaa I.: A survey on gas leak detection and localization techniques. Journal of Loss Prevention in the Process Industries 2012, vol. 25, s. 966-973.

[17] Rachwalski J. i in.: Wybór metod przydatnych do opracowania szybkiej metody pomiaru emisji gazu z liniowych $i$ kubaturowych obiektów przemysłu gazowniczego. Praca na zlecenie Ministerstwa Nauki i Informatyzacji 2005, s. 4, nr zlecenia: 0051/GE/2005, nr archiwalny: 411/E-271/S/2005/51.

[18] Rataj M., Basiura M.: Wykrywanie emisji gazów węglowodorowych przy wykorzystaniu kamery termowizyjnej FLIR GF320. Gaz, Woda i Technika Sanitarna 2012, nr 9, s. 366-369.

[19] Safirti A., Gao X., Mannan M.S.: Dispersion modeling approach for quantification of methane emission rates from natural gas fugitive leaks detection by infrared imaging technique. Journal of Loss Prevention in the Process Industry 2011, vol. 24, s. $138-145$.

[20] Steczko K., Rachwalski J.: Emisja metanu z sieci rozdzielczej gazu ziemnego. Nafta-Gaz 2007, nr 6, s. 412-423.

\section{Akty prawne i normatywne}

[21] PN-EN 15446:2008 Niekontrolowana i rozproszona emisja w sektorze przemystowym - Pomiar emisji par wydobywajacych się z nieszczelnych instalacji i przewodów.

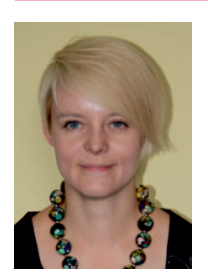

Mgr Jadwiga HOLEWA-RATAJ

Starszy specjalista badawczo-techniczny w Zakładzie Ochrony Środowiska.

Instytut Nafty i Gazu - Państwowy Instytut Badawczy ul. Lubicz 25 A

31-503 Kraków

E-mail: jadwiga.holewa@inig.pl

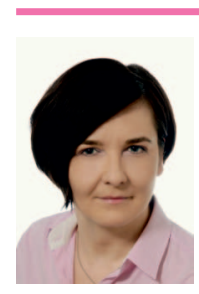

Dr Ewa KUKULSKA-ZAJAC

Adiunkt; kierownik Zakładu Ochrony Środowiska. Instytut Nafty i Gazu - Państwowy Instytut Badawczy ul. Lubicz $25 \mathrm{~A}$

31-503 Kraków

E-mail:kukulska@inig.pl 